Portland State University

PDXScholar

Institute for Sustainable Solutions Publications

and Presentations

Institute for Sustainable Solutions

$1-1-2009$

\title{
Toward a new sustainable economy
}

Robert Costanza

Portland State University

Follow this and additional works at: https://pdxscholar.library.pdx.edu/iss_pub

Part of the Sustainability Commons

Let us know how access to this document benefits you.

\section{Citation Details}

Costanza, Robert (2009). "Toward a new sustainable economy," Real-World Economics Review 49: 20-21.

This Article is brought to you for free and open access. It has been accepted for inclusion in Institute for Sustainable Solutions Publications and Presentations by an authorized administrator of PDXScholar. Please contact us if we can make this document more accessible: pdxscholar@pdx.edu. 


\title{
Toward a new sustainable economy
}

\author{
Robert Costanza [University of Vermont, USA]
}

The current financial meltdown is the result of under-regulated markets built on an ideology of free market capitalism and unlimited economic growth. The fundamental problem is that the underlying assumptions of this ideology are not consistent with what we now know about the real state of the world. The financial world is, in essence, a set of markers for goods, services, and risks in the real world and when those markers are allowed to deviate too far from reality, "adjustments" must ultimately follow and crisis and panic can ensue. To solve this and future financial crisis requires that we reconnect the markers with reality. What are our real assets and how valuable are they? To do this requires both a new vision of what the economy is and what it is for, proper and comprehensive accounting of real assets, and new institutions that use the market in its proper role of servant rather than master.

The mainstream vision of the economy is based on a number of assumptions that were created during a period when the world was still relatively empty of humans and their built infrastructure. In this "empty world" context, built capital was the limiting factor, while natural capital and social capital were abundant. It made sense, in that context, not to worry too much about environmental and social "externalities" since they could be assumed to be relatively small and ultimately solvable. It made sense to focus on the growth of the market economy, as measured by GDP, as a primary means to improve human welfare. It made sense, in that context, to think of the economy as only marketed goods and services and to think of the goal as increasing the amount of these goods and services produced and consumed.

But the world has changed dramatically. We now live in a world relatively full of humans and their built capital infrastructure. In this new context, we have to first remember that the goal of the economy is to sustainably improve human well-being and quality of life. We have to remember that material consumption and GDP are merely means to that end, not ends in themselves. We have to recognize, as both ancient wisdom and new psychological research tell us, that material consumption beyond real need can actually reduce well-being. We have to better understand what really does contribute to sustainable human well-being, and recognize the substantial contributions of natural and social capital, which are now the limiting factors in many countries. We have to be able to distinguish between real poverty in terms of low quality of life, and merely low monetary income. Ultimately we have to create a new model of the economy and development that acknowledges this new full world context and vision.

This new model of development would be based clearly on the goal of sustainable human well-being. It would use measures of progress that clearly acknowledge this goal. It would acknowledge the importance of ecological sustainability, social fairness, and real economic efficiency. Ecological sustainability implies recognizing that natural and social capital are not infinitely substitutable for built and human capital, and that real biophysical limits exist to the expansion of the market economy.

Social fairness implies recognizing that the distribution of wealth is an important determinant of social capital and quality of life. The conventional model has bought into the assumption that the best way to improve welfare is through growth in marketed consumption 
as measured by GDP. This focus on growth has not improved overall societal welfare and explicit attention to distribution issues is sorely needed. As Robert Frank has argued in his latest book: Falling Behind: How Rising Inequality Harms the Middle Class, economic growth beyond a certain point sets up a "positional arms race" that changes the consumption context and forces everyone to consume too much of positional goods (like houses and cars) at the expense of non-marketed, non-positional goods and services from natural and social capital. For example, this drive to consume more positional goods leads people to reach beyond their means to purchase ever larger and more expensive houses, fueling the housing bubble. It also fuels increasing inequality of income which actually reduces overall societal well-being, not just for the poor, but across the income spectrum.

Real economic efficiency implies including all resources that affect sustainable human well-being in the allocation system, not just marketed goods and services. Our current market allocation system excludes most non-marketed natural and social capital assets and services that are critical contributors to human well-being. The current economic model ignores this and therefore does not achieve real economic efficiency. A new, sustainable ecological economic model would measure and include the contributions of natural and social capital and could better approximate real economic efficiency.

The new model would also acknowledge that a complex range of property rights regimes are necessary to adequately manage the full range of resources that contribute to human well-being. For example, most natural and social capital assets are public goods. Making them private property does not work well. On the other hand, leaving them as open access resources (with no property rights) does not work well either. What is needed is a third way to propertize these resources without privatizing them. Several new (and old) common property rights systems have been proposed to achieve this goal, including various forms of common property trusts.

The role of government also needs to be reinvented. In addition to government's role in regulating and policing the private market economy, it has a significant role to play in expanding the "commons sector", that can propertize and manage non-marketed natural and social capital assets. It also has a major role as facilitator of societal development of a shared vision of what a sustainable and desirable future would look like. As Tom Prugh, myself, and Herman Daly have argued in our book "The Local Politics of Global Sustainability," strong democracy based on developing a shared vision is an essential prerequisite to building a sustainable and desirable future.

\section{Conclusion}

The long term solution to the financial crisis is therefore to move beyond the "growth at all costs" economic model to a model that recognizes the real costs and benefits of growth. We can break our addiction to fossil fuels, over-consumption, and the current economic model and create a more sustainable and desirable future that focuses on quality of life rather than merely quantity of consumption. It will not be easy; it will require a new vision, new measures, and new institutions. It will require a redesign of our entire society. But it is not a sacrifice of quality of life to break this addiction. Quite the contrary, it is a sacrifice not to.

Robert.Costanza@uvm.edu

SUGGESTED CITATION:

Robert Costanza, "Toward a new sustainable economy”, real-world economics review, issue no. 49, 12 March 2009, pp. 20-21, http://www.paecon.net/PAEReview/issue49/Costanza49.pdf 